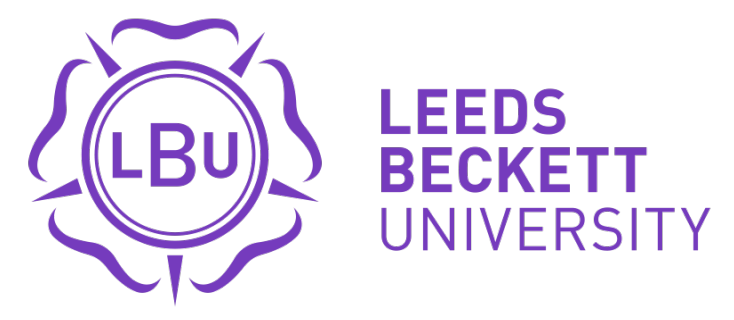

Citation:

Edwards, B (2018) Shops on A-Deck: Transatlantic Consumption, the Masculine Tourist and the Metropolitanisation of the Ocean Liner. History of Retailing and Consumption, 4 (3). pp. 235-254. ISSN 2373-518X DOI: https://doi.org/10.1080/2373518X.2018.1551473

Link to Leeds Beckett Repository record:

https://eprints.leedsbeckett.ac.uk/id/eprint/5581/

Document Version:

Article (Accepted Version)

The aim of the Leeds Beckett Repository is to provide open access to our research, as required by funder policies and permitted by publishers and copyright law.

The Leeds Beckett repository holds a wide range of publications, each of which has been checked for copyright and the relevant embargo period has been applied by the Research Services team.

We operate on a standard take-down policy. If you are the author or publisher of an output and you would like it removed from the repository, please contact us and we will investigate on a case-by-case basis.

Each thesis in the repository has been cleared where necessary by the author for third party copyright. If you would like a thesis to be removed from the repository or believe there is an issue with copyright, please contact us on openaccess@leedsbeckett.ac.uk and we will investigate on a case-by-case basis. 
Bronwen Edwards, School of the Built Environment and Engineering, Leeds Beckett

University, Northern Terrace, Queen Square Court, Leeds LS2 8AG,

b.edwards@leedsbeckett.ac.uk

\title{
Shops on A-Deck: Transatlantic Consumption, the Masculine Tourist and the Metropolitanisation of the Ocean Liner.
}

\begin{abstract}
This article is about the branches of fashionable London menswear retailers on ocean liners 1930 - 1960. It examines the design and spaces of shops on Cunard liners, and the connected discourses about masculine consumption cultures and geographies contained in trade journals, advertising and business records.

The article draws together perspectives from consumption and design histories and geographies. It addresses the intersection between men's fashion, consumption and travel geographies on liner decks. It considers how metropolitan menswear retailers, adjusting to changing overseas markets, engaged with transatlantic leisure travel cultures. This created a complex web of production, retail and consumption spanning the Atlantic, whilst also demonstrating the elasticity of metropolitan consumption geographies.
\end{abstract}

This study of liner shops re-examines the urban, 'located' nature of mid twentieth century fashionable consumption culture. It rethinks the 'otherness' of historic maritime life, repositioning the interior of the ocean liner as an extension of and staging of West End consumption space. It is also explored as a place of transformation, for preparing for the metropolitan.

Keywords: menswear; retail geography, twentieth century consumption; leisure consumption; liners; retail design

\section{Introduction:}




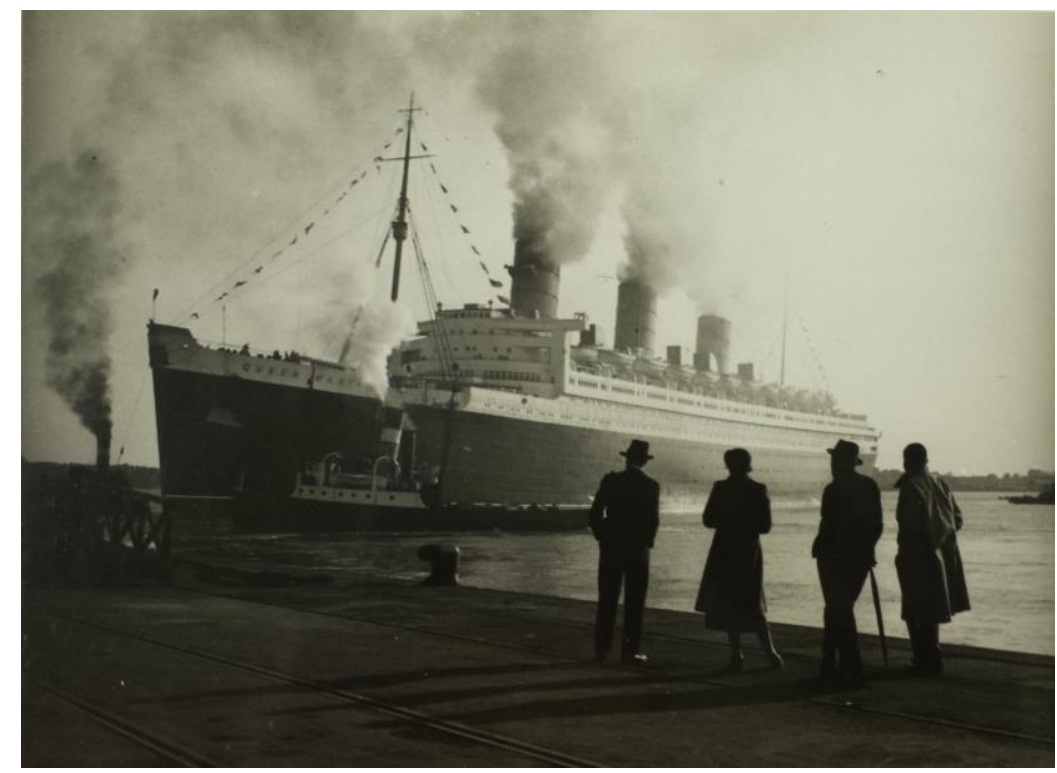

Figure 1. The maiden voyage of the R.M.S. Queen Mary, Stewart Bale Photographer (1936) By courtesy of the University of Liverpool Library, Cunard Archive (Stewart Bale), D42/PR2/97/C27

Amid the board minutes and press releases of the Cunard liner company's archive is a publicity photograph of the R.M.S. Queen Mary's maiden voyage. Four figures are silhouetted against the sleek, modern lines of the ship in the early morning light. Three men and a woman, their clothes are smart and new: well-fitting suits, overcoats and fashionably-angled hats. It is as if they had just stepped out of an elegant modern clothes shop, freshly equipped for transatlantic travel. (Figure 1) Images like this were intended to speak to North American tourists in addition to the British market. Big London retailers now had substantial marketing budgets, and some spent a significant amount on advertisements in the special liner newspapers like the Ocean Times. Whilst rarely explicitly stated, the content and context of the advertisements suggests that affluent American men were the primary target. These papers were published for each sailing from onboard print rooms, hidden in the bowels of the ship. 
In 1936, upmarket man's shop Simpson Piccadilly placed a typical advertisement in the SS Normandie's paper, 'The evening tail coat ... is not only a perfect symbol of the Englishman's far-famed formality - it exactly represents that something extra by which the Englishman sets the fashion for the world in the matter of clothes. ${ }^{1}$ At the same moment, Simpsons' main West End competitor, Austin Reed, was going further, opening well stocked micro-shops aboard the ocean liners themselves.

This article is about the role of retail and consumption in the mid-century leisure cultures of a privileged community of affluent masculine maritime travellers, especially Americans travelling from New York to Southampton. It looks at how men's fashion, consumption and travel geographies intersected aboard the ocean liner, and at how upmarket menswear retailers adapted their business practices and networks to profit from this intersection. These retailers' strategies of store positioning, design and advertisement were part of complex international marketing efforts by British businesses, as they adjusted to changed overseas markets, tourism and imperial structures. These strategies were important ways of reaching the mobile market of transatlantic travellers, on one hand familiarising an unfamiliar space, and on the other exploiting the destabilising nature of sea travel. The research therefore has implications for histories and geographies of consumption and retail, problematizing ideas about the urban flavour and locatedness of fashionable consumption through an examination of the convergence of the metropolitan and the transatlantic.

The study examines the phenomenon of branches of fashionable ready-to-wear menswear shops springing up on the promenade decks of mid twentieth century transatlantic liners. It looks specifically at Austin Reed and Simpson Piccadilly's activities on the R.M.S Aquitania, R.M.S. Queen Mary and Queen Elizabeth. In 1929, the aging Aquitania provided Austin Reed with its first onboard retailing opportunity, 
their store built in fits and starts between regular sailings. However, the menswear shops on the Queen Mary and Queen Elizabeth, the brand new stars of Cunard's fleet were an integral part of the original designs, and attracted the most attention. The Queen Mary's maiden voyage from Southampton to New York was in 1936. The first sailing of the Queen Elizabeth, launched in 1938, was delayed until 1946 due to outbreak of war. ${ }^{2}$ This was the heyday of liner travel and tourism, and whilst still largely the province of the affluent, it was becoming more accessible. The capacity of the Queen Mary was for 776 cabin class passengers, 784 tourist class, 579 third class, with 1101 officers and crew. ${ }^{3}$ The cabin and tourist classes were the primary markets, but even so this represented an attractive captive market for retailers and advertisers during the leisurely 4-day sailings where time could drag.

Menswear retailing, and chain stores more generally, were thriving, as $\mathrm{Mr}$ Taylor Rose of Austin Reed expressed, ‘The men's wear business today has risen from a position of obscurity to one of some importance in commercial life. ${ }^{4}$ Within this broader context, this study focuses on the group of businesses identified in the sector as the 'better end of the trade'. ${ }^{5}$ During the 1930s, upmarket ready-to-wear menswear retail flourished, and the chain Austin Reed and men's department store Simpson Piccadilly were UK market leaders. ${ }^{6}$ Their business expansion reflected the burgeoning fashionability and respectability of this class of ready-made tailoring. Both companies were strongly embedded in London's West End where their flagship stores were based, and they had one eye on the profits of neighbouring Savile Row. ${ }^{7}$ 


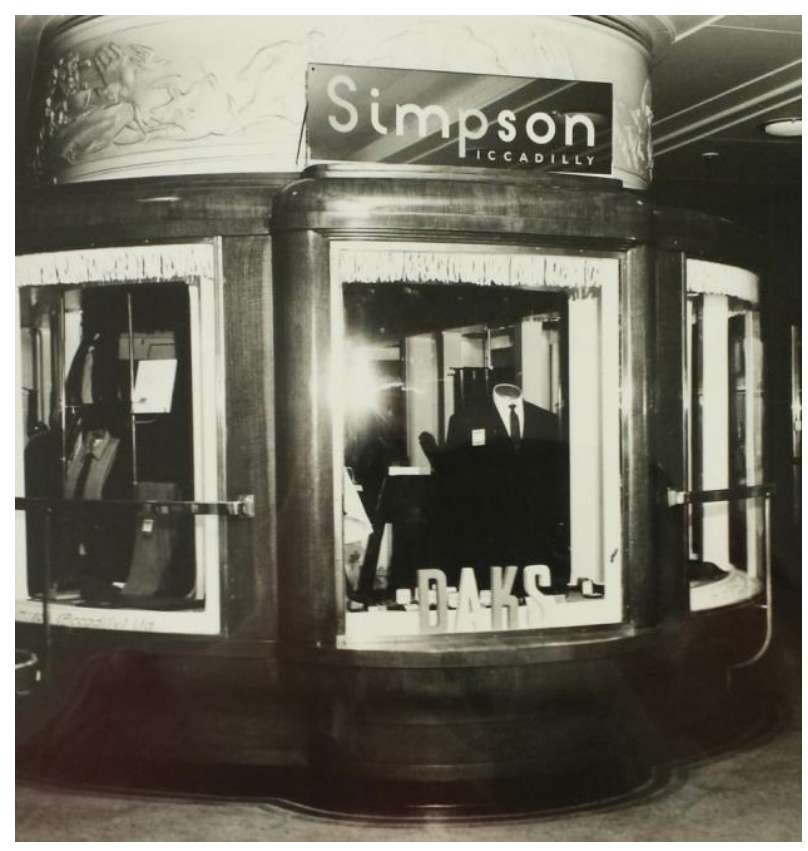

Figure 2 Simpson's shop on the Queen Mary Cunard Company Archives, University of Liverpool (c. early 60s). By courtesy of the University of Liverpool Library, Cunard Archive D42/PR2/1/97D/D133

This article brings the spatial perspectives of historical geography to a study of retail practices, consumption culture, gender and design. The research has drawn on records of the Cunard liner company, the archival collections of British menswear retailers, and architectural and menswear trade journals. Mid twentieth century retail business records, advertising and store designs have been especially useful. Understandings of advertising had developed significantly by the 1930s, and leading menswear retailers were investing heavily in its potential. They employed the most modern and innovative firms, and the value placed on their work product is reflected in archival collections. ${ }^{8}$ Records also show that store architecture and design strategies were evolving, harnessed ever more effectively as a promotional tool. Architectural plans and record photography of 'significant' new shops were reproduced in the architectural trade press, and the liner shops were amongst these. 
However, menswear was not a primary concern of the liner company, neither were the liner shops the priority of the retailers. Where evidence existed, it was often in asides in everyday business communications, in ephemera, or captured by chance. Traces were found in photographs capturing key moments: publicity images of ghostly, empty ships taken in advance of their launch; local newspaper accounts of the excitement of the maiden voyage; the record photography for internal renovations, annotated with measurements and colour schemes. The insights of this article result from setting these different kinds of archival material alongside each other, considering the spaces, practices and cultures they evoke. The direct perspective of the masculine consumer himself is elusive. Collectively, the translucent paper of architects' plans and directors' memos, rich glossy blackness of photographs and the acid-crumbled remnants of newsprint present a narrative about him. In this narrative the tailored suit, hosiery, shoes, shirts, and the spaces where they were displayed, stored and promoted, all had important roles. During this whole period, Cunard had offices in Regent Street, near neighbours of both Austin Reed's flagship store, and around the corner from Simpson Piccadilly. It is easy to imagine ideas being floated and deals done in the gentlemen's clubs in Jermyn Street, by Simspons' back door.

The article's concentration on upmarket menswear adds to the substantial research by Honeyman and Ugolini on the significant development of more affordable ready-to-wear menswear early to mid twentieth century, and the nuanced relationship between ready-made and tailored clothing. ${ }^{9}$ This study's focus on the retail spaces of ocean liners also contributes to understandings of metropolitan nature of fashionable masculine consumption. ${ }^{10}$ Conceptualising nineteenth and twentieth century fashionable consumption cultures as urban, and tied to their specific geographies, has been central to the way we frame research about modern retail, notwithstanding the way flourishing 
chains and brands foreshadowed fears of the 'clone town'. ${ }^{11}$ This article demonstrates that the materiality of shops and invocation of city streets remained important elements of liner consumption. The interior of the ocean liner is suggested in part as an extension of metropolitan space, specifically 'West End' space, in several key respects. At the same time, it was a place of transformation, where tourists and travellers prepared for the metropolitan. Both liner and West End were places of leisure and tourism. Understandings of historical consumption in retail spaces such as the department store and mall as 'leisure activity' are now well established. ${ }^{12}$ The article is positioned amongst studies of new attempts by mid twentieth century retailers to harness the business potential of consumption beyond their urban stores and shopping streets within the geographies and spaces of travel and holidays. Notable here is Longstreth's discussion of North American department stores' establishment of hotel concessions. ${ }^{13}$

Here, intersections are made with powerful historical geographical work on the sea and the ship as 'other space', ${ }^{14}$ and equally with design historians' description of the ocean liner as 'dream object' and 'heterotopia'. ${ }^{15}$ Their work has convincingly argued against the consideration of the sea as a place where land cultures are simplistically transposed. Whilst this article's research has encountered retailers' insistence on the urban identity of the liners' retail promenades, the geographical perspective has been helpful in unsettling ideas about urban, and particularly, metropolitan consumption and masculinity.

Bringing a geographical perspective to the consumption and leisure spaces of the liner additionally engages with the design histories of the liner's discussion of national identity, class and modernity. ${ }^{16}$ This was a time when nations invested heavily in these commercial projects, buying the ability to shape designs and exploit promotional potential. These studies examine Le Corbusier's famous claiming of the liner as an icon 
of sleek, functional international modernism, and note architects' dismay at liner interiors. ${ }^{17}$ The plush, luxury interiors and their fashionable consumption spaces proved a bit of a problem for modernist discourse. By considering the spaces and designs of liner shops in a more complex geographical context, within networks of consumption, travel, design and masculine identities, this article offers insights on the shifting relationship between these things.

The first part of the article examines the mapping and networking of the retail process, looking at the position of onboard consumption within wider geographies of masculine consumption. It reflects on the way transatlantic travel related to the phased nature of traditional and modern production of tailored garments for men. This section also considers the role of liner newspaper advertising and editorial in sketching out imagined international geographies of fashionable masculinity, with the West End at the centre. The second strand turns to the layout, design, shopfitting and display practices of the onboard shops. It considers how the material spaces, surfaces and shop windows worked alongside retail advertisements to map the relationship with the mainland. It investigates he role of the shops and by extension the liner interior spaces as a whole as West End outposts. The article ends with an examination of the relationship between tradition and modernity within the fashionable masculinities promoted by retailers to American customers in comparison with domestic markets, as they exploited the anxieties of consumers away from home.

\section{'Am I to understand... that you actually have a branch shop on the Aquitania?': mapping and networking the retail process}

This section maps the retail spaces, networks and practices that connected shops in the 
West End with those on the promenade decks of liners. It shows how design and advertising strategies could collapse distances between the ocean and urban shopping street, showing how metropolitan consumption geographies could be fluid and elastic.

Fashionable clothes were at the centre of retailers' obscuring of 'real' geographies. The shape of the cruising, tourist masculine body-in-motion was sketched in the onboard and mainland shops' displays and stocks of garments and services. Domestic retail operations marketed clothing for liner travel, within the fashionable masculine consumer's wardrobe of occasion-specific outfits for town, beach, golf, weekend, tennis, formal dress wear. ${ }^{18}$ Regular seasonal shop window displays and dedicated departments featured clothes for cruising and liner travel. In 1952, Simpsons staged an exhibition on holiday cruises and fashion show in its London store, 'in addition to the four attractive women models who displayed the beach-wear, resort fashions and swim suits, two male models who wore with distinction our Daks light-weight suits, evening wear and the newest things in men's beach-wear.' ${ }^{19}$ The store courted representatives from liner companies and the wider travel industry, in addition to favoured customers, through these glamorous events. Significantly, Simpson's Piccadilly shop included a Thomas Cook travel agent concession where cruises could be booked, completing the package.

British menswear manufacturing and retail trade journals show that the fashions and rhythms of modern tourist cultures structured business as much as traditional clothing seasons. Special shipping numbers of Menswear journal publicised international opportunities, impressing on overseas readers that 'London sets the styles for masculine modes the world over, and men's wear specialists in all parts of the globe habitually turn to the Metropolis for sartorial inspiration. ${ }^{, 20}$ Conversely, the fashionable but casual American tourist was frequently sold as an aspirational model for the London 
market, an indication of the shifting international geographies of masculine fashion. An advert in the Evening News advised, 'you can only get them at Simpsons: ... American Blinkers (sunglasses), terry sweat shirt, reversible bather.' ${ }^{21}$

There were several ways for retailers to extend their geographical reach in this era of more accessible transatlantic travel. London's traditional Savile Row tailors made important efforts to ply their trade to international, especially American, customers. However, the difficulty of aligning timelines of making and travelling/touring presented problems for traditional tailoring. Garments were handmade and required sequential appointments for measurements and fittings bringing tailor and customer together in one place.

One response to this challenge was demonstrated by London tailors Thresher and Glenny, who advertised themselves in the Ocean Times as 'London Tailors to America': 'American friends who get their personal patterns and details established with us whilst in England may take delivery of their orders on returning to the United States... Thresher and Glenny have tailored for Americans since 1861 and representatives visit the USA each spring and autumn to take orders and contact new customers. ${ }^{22}$ However this model of service risked inconveniences and delays.

The interwar emergence of fashionable, quality, ready-to-wear 'tailoring' had the potential to transform the challenges of time and geography, especially given these firms' association with market-leading advertising. By 1939, Austin Reed was advertising in Reuter's Bulletin, the Ocean Press and Ocean Times in addition to extensive domestic campaigns. The advertising trade journal Art and Industry commented that the retailer's publicity 'has made most of us (whether in Britain or abroad) "Austin Reed conscious" since we were old enough to read'. ${ }^{23}$ 
The suits sold by this new breed of menswear retailer were not bought 'off the peg' in the contemporary sense. Rather, they were still usually subject to minor or major in-store alterations, as were less complex and structured garments such as overcoats. The emphasis in advertising on quality of fabric, design and this layer of traditional hand-making was used as a means differentiating these garments from more downmarket brands, notwithistanding the frequent use of alteration services in that sector too. The trick was to give these upmarket ready-made clothes a touch of 'Savile Row'. The new onboard shops created possibilities for advance ordering, fittings, deliveries, streamlining the protracted processes of suiting the consumer, so that the onboard branches could work effectively in conjunction with the mainland flagships to serve the tourist market. Onboard sales staff were drawn from mainland shops, ensuring continuity of culture and service within the network.

A 1930 Austin Reed advertisement highlights the unfamiliarity of this new network of production, retail and consumption. It recounted the visit of a fictional American customer to their Regent Street shop, as means of guiding prospective customers through the process,

“"I'm only sorry I can't get some English suits and overcoats while I'm here. I'm sailing on Saturday on the Aquitania". We pointed out that we could supply him with everything connected with the masculine wardrobe from hats to shoes. "Am I to understand that you have a Ready-for-Service Tailoring Department?" We said he was... We arranged to make the few necessary tailoring alterations that day and to deliver the goods to the Aquitania. An hour later a 'phone call came through. "Supposing", he said, "your stuff arrives on the Aquitania and some of the alterations are not just O.K.?" We explained that the idea was almost inconceivable, but if any goods did not afford complete satisfaction it 
was only necessary to apply to our shop on A. Deck where any such garment would be exchanged or the price refunded, whichever he preferred. "Am I to understand, "he said in awestruck tones, "that you actually have a branch shop on the Aquitania?"24

Complex and shifting mid-century geographies of store reputation and clothing production and retail were mapped out in these business practices and advertisements, and the liner shops were positioned as stages in the transformation of the London-bound American tourist. The route plotted was New York to ocean liner to London. It was of course Southampton and not London where the Cunard liner docked, but Southampton was quietly edited out of the fashionable map. This geography was illustrated in a grand mural mapping the North Atlantic by artist McDonald Gill, looming above the First Class restaurant of the Queen Mary. An illuminated liner moved across the mural during the journey, plotting the ship's course. This geography was repeatedly drawn in advertising for both the domestic and tourist markets. 


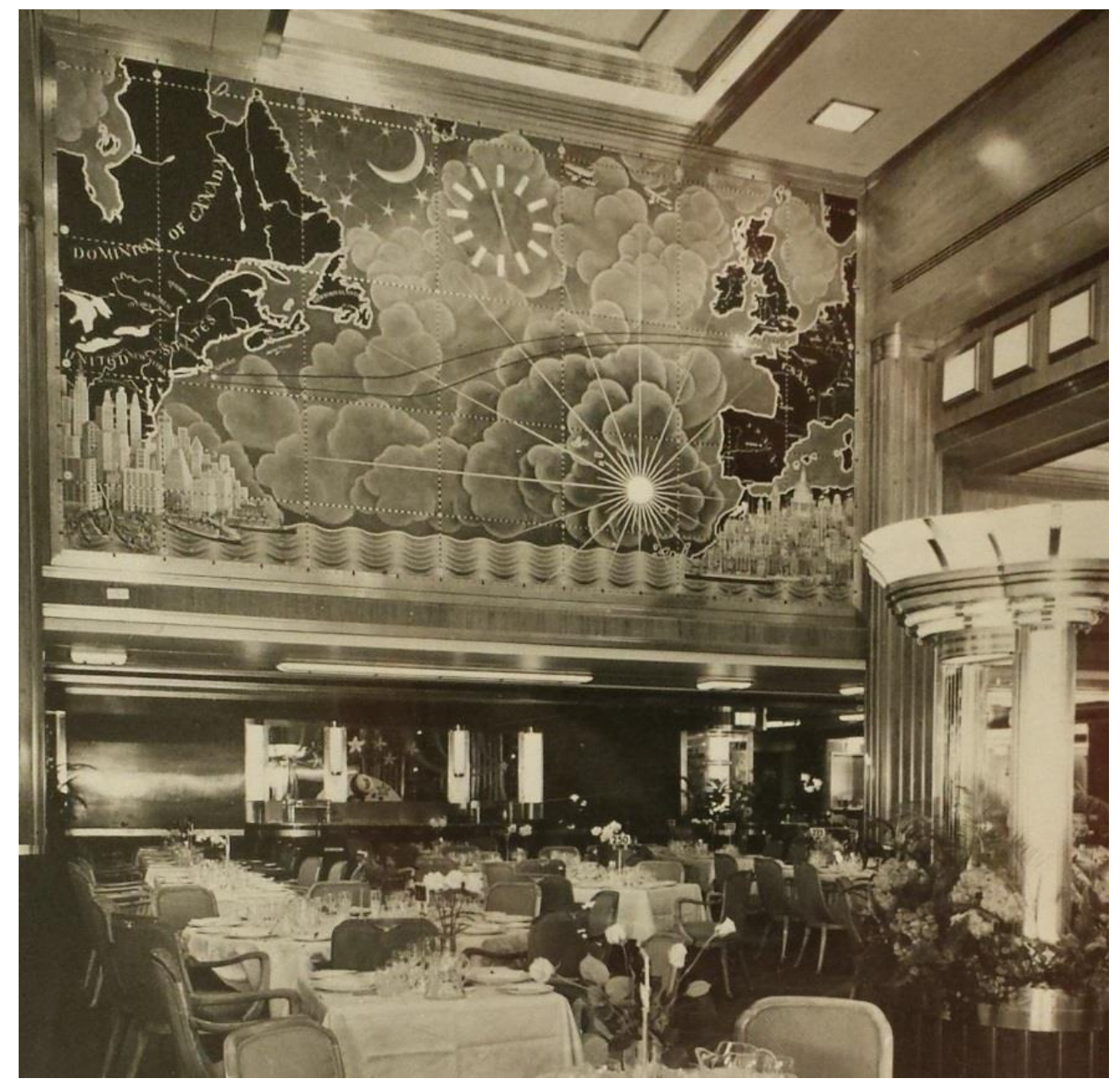

Figure 3: Queen Mary's First Class restaurant, 1936. By courtesy of the University of Liverpool Library, Cunard Archive, D42/PR2/1/97C/C27.

It was established practice for West End businesses to invoke London-centric colonial geographies in their promotional material. For example, a typical advertisement by the jewellers Asprey in the Ocean Times Queen Elizabeth edition from 1947, 'The world comes to Bond Street, and from Bond Street Asprey send out their wares for those who, the world over, value the reserve and dignity of English craftsmanship' ${ }^{25}$ This message was prominent at moments of heightened international attention (for example the Coronations of 1937 and 1953). It was equally insistent at moments of disruption and change, for example the straightened economic circumstances of the 1930s and in the difficult years following World War Two. 
The post-war years provided an opportunity for Simpson Piccadilly to establish a foothold on the liner deck, following the lead of competitor Austin Reed. Liners which had been requisitioned for war work were now being decommissioned, refitted and repurposed for the luxury leisure travel business. ${ }^{26}$ Simpson's store minutes record how important this market was still felt to be. Plans were made in the aftermath of a management visit to the USA 'it was agreed that we should again explore the possibilities of having a shop on the best ocean liners, and that Crawfords [advertising firm] should consider the question of advertising in ocean liner newspapers. ${ }^{27}$ After experimenting with shorter term display cases and exhibitions on liners during the 1950s, Simpsons took over Austin Reed's shops on the Queen Mary and Queen Elizabeth during the early 1960s.

Fashionable West End retailers filled the advertising pages of the issues bound for England. They presented London's shops as key elements of the tourist map, and shopping as integral to tourist cultures. A 1947 advertisement for Liberty's of Regent Street in the Ocean Times included the text 'The world's most beautiful shop is really Elizabethan. Its great oak timbers were carved as they stand, just as they would have been in the $16^{\text {th }}$ century. And it is appropriate that this famous building should be Liberty's, for only Liberty's have brought to London such a vast store of beautiful treasures from the most distant countries of the world, since the merchant navies of Gloriana last came home from the Spanish Main. You will visit Liberty's; everybody must ${ }^{28}$ A similar message was conveyed in a 1950s Simpson Piccadilly menswear catalogue, distributed via mailing lists and satellite stores, 'Half an hour spent browsing about here, in London's most modern man's store, is almost as good as a holiday in itself' $^{29}$

For these West End retailers, the onboard publications were important selling 
sites. Editorials also wrote about the destination city at each end, enabling retailers to draw on this narrative in their own constructions. The England-bound issues of the Ocean Times regularly included features on the cultures and geography of elite British life. They described West End shopping streets in a style that fell somewhere between guidebook and advertisement, directed at American passengers. In a typical article, 'London's Heart', the thoroughfares, arcades and backstreets of the Piccadilly Circus / St James's area were sketched, 'Piccadilly soon reveals itself as a shopping street of distinction, for within a short distance of each other are Simpson's and Fortnum \& Mason. Simpson's specialise in the requirements of both the fashionable man-abouttown and the well-dressed man of the country, and their range of accessories is of the latest, while they also have a special flair for the up-to-the-minute young woman's tastes - especially in sweaters and smart casual wear. ${ }^{30}$ Editorial and advertisements were almost indistinguishable, working closely together to evoke the West End street.

Retailers often used images of the store facades in advertisements, punctuating the tourist's imagined West End with landmark store buildings. A 1960s advertisement for Simpson Piccadilly is typical in this respect, including a detailed architectural drawing of the landmark building and also a store guide. ${ }^{31}$ It is positioned next to a revised version of the 'London's Heart' article, writing on Jermyn Street (where Simpson's back entrance was positioned) 'Nothing ruffles the typically English calm of St. James's except possibly in Jermyn Street. Here is a man's street par excellence. Fashion-conscious men find this part of London's heartland a boon or it features a prodigious range of luxurious clothes and accessories. ${ }^{32}$ These advertisements fed back into stores' domestic strategies of using the architecture of store facades as a marketing device within the actual street. Retailers had become expert at both drawing in customers from their pavement with spectacular design, and also staking a prominent 
position on the tourist route through 'landmark' architecture. As Commercial Art explained, 'The direct appeal to the aesthetic sense that the shops exert is more effective in impressing the public with the concept of quality than any amount of persuasive advertising copy' ${ }^{33}$ Austin Reed and Simpson Piccadilly both had particularly effective architectural strategies. P. J. Westwood and Sons handled all of Austin Reed's stores. They were the sector-leading British retail architecture firm. ${ }^{34}$ Joseph Emberton, the architect of Simpson Piccadilly, had also previously designed for Austin Reed among other retail clients, in addition to work on significant exhibition buildings and stands. In a lecture given to the Design and Industries Association in 1937, Emberton addressed importance of the shopfront as publicity. ${ }^{35}$ 


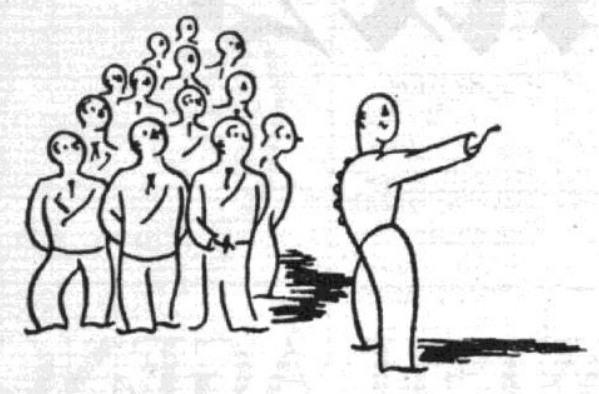

\section{How to find us}

There are two Austin Reed shops on board the Queen Elizabeth. One on the First Class Main Deck, cheek by jowl, as it were, to the barber's shop. And another on the Cabin Class Promenade Deck, next to the Library and the Theatre. Most men find, after they have unpacked, that they have nothing of something, and it is part of the Austin Reed Service to supply the missing necessities to harassed gentlemen. There are bolder spirits, of course, who never bother to find an excuse for enjoying shopping at Austin Reed's.

\section{A U S T I N R E E D \\ OF REGENT STREET, LONDON \\ (A Queen Elizabeth's length from Piccadilly Circus)}

Figure 4 Austin Reed Advertisement, Ocean Times Queen Elizabeth edition (20 January 1947): 2. By courtesy of the British Library.

Ocean Times advertisements for onboard and West End stores shared a preoccupation with mapping and navigation. They suggest retailers believed that men needed to be told exactly how to find a shop, how to plot a course within it, and how to consume. (See figure 4) Like the artist of the Queen Mary's atlantic map mural, the liner companies and retailers were playing with geographies and distorting distances. 
They diminished the strangeness of British masculine fashions for Americans by suggesting an almost seamless walk between New York's Madison Avenue and London's Regent Street by way of the liner deck. However, they were simultaneously stressing London's role as an important and aspirational consumption venue for the foreign tourist. Strategies of design proved an important means of navigating this complexity.

'The traveller in the Queen Mary is greeted with a complete "Regent Street" of fashionable shops'

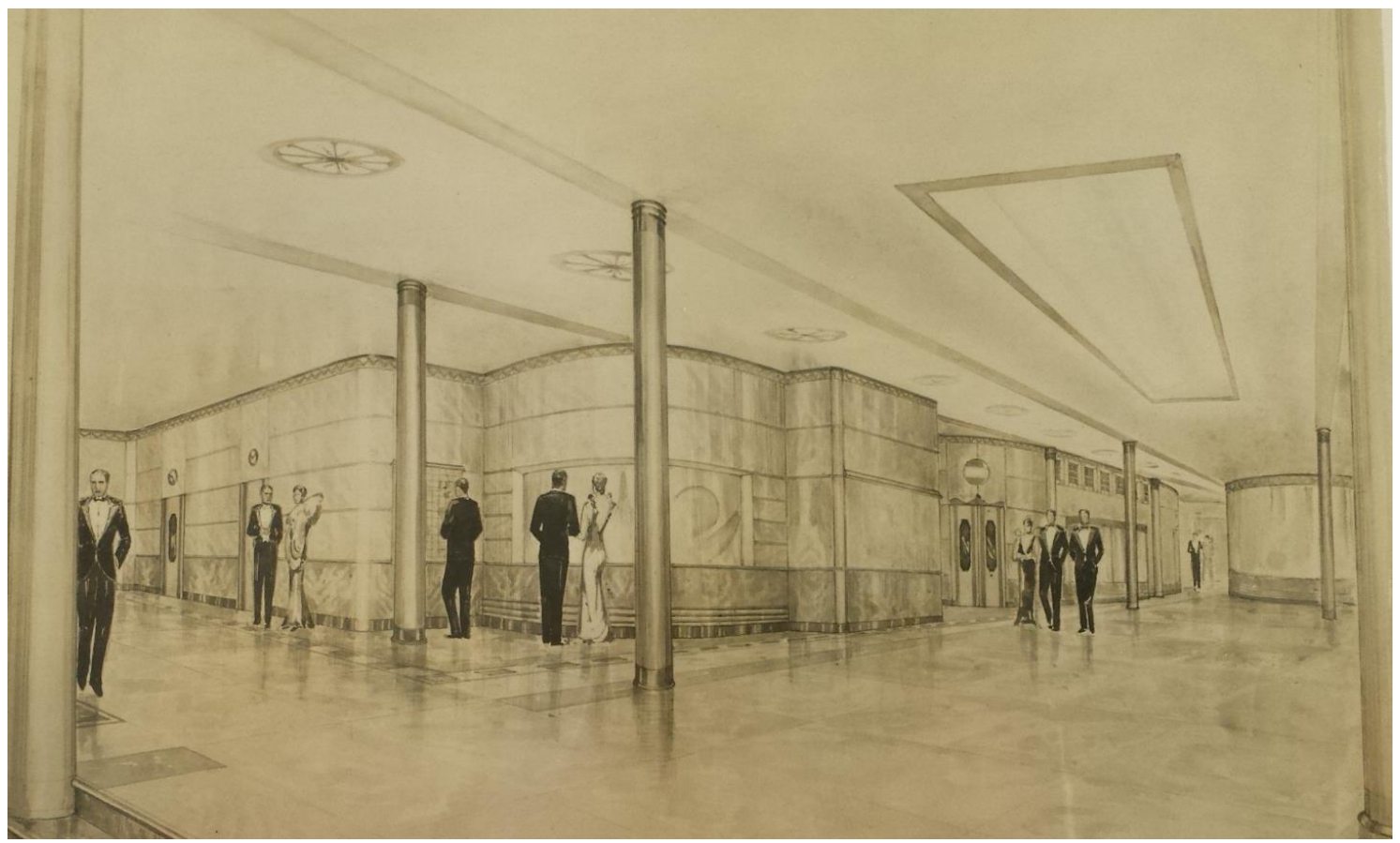

Figure 5. Designs for the shopping centre on Queen Mary's promenade deck (c.1936).

By Courtesy of the University of Liverpool Library, Cunard Archive,

D42/PR2/1/97/D137

The owner of Simpson Piccadilly wrote on the eve of the opening of his West End shop 
'I feel very much like the captain of a big new ship waiting for the pilot in charge of the tugs to get him out of the dock, so that I can sail spick and span on my maiden voyage. ${ }^{36}$ This section considers how the spatial ordering, design, shopfitting and display practices in the onboard shops worked alongside the advertising text and image to craft a relationship with the mainland. They collectively identified the liner shop as a metropolitan space, specifically a West End outpost, with all the connotations of fashionable consumption that invoked. Whereas the Ocean Times conjured up the shopping streets of London or New York, depending on the direction of travel, the promenades of the liners, as inhabited, represented and imagined spaces, were permanently linked through materials, design, display and planning to West End streets. As a commemorative guide of the new Queen Mary expressed, 'In the Main Hall, situated on the Promenade Deck, the traveller in the Queen Mary is greeted with a complete "Regent Street" of fashionable shops'. ${ }^{37}$ This " "Regent Street" of the ship' staged upmarket leisure consumption so that 'we may be 1000 miles from the nearest land, and yet here are shops open for us to stroll into and make our purchases just as easily as if we were ashore'. ${ }^{38}$ Whilst the photographs and plans show spaces reminiscent of the London arcade and American mall, Austin Reed was insistent on linking with the outdoor sweep of Regent Street, it was on this connection with their mainland Regent Street flagship that the business strategy depended.

The liner interior and shop shared an approach to design that was less about modernity of structure, than of style, surface, veneer, decoration. (see figure 5) The Queen Mary was celebrated for the luxurious modern treatment of interior spaces: wall coverings, floorings, decorative art and furnishings. The architects in charge of interiors were specialist liner designers Arthur J Davis ARA, FRIBA and Benjamin W. Morris FAIA. The bulk of shopfitting was by George Parnall and Co. Ltd, with Austin Reed's 
regular architects P. J. Westwood and Sons in charge of designing their particular shop (as for the Aquitania and Queen Elizabeth shops). The spacious ninety-foot shopping deck had a skin of luxury woods and metals and large jardinières of fresh flowers. ${ }^{39}$ Architecture Illustrated noted how Austin Reed's cabin class shop stood out from the 'restrained brown tones of the chestnut' of the arcade, 'The interior of this central shop has been constructed mainly in Indian silver greywood, with bands of Indian laurel wood, both of which are richly figured. ${ }^{40}$

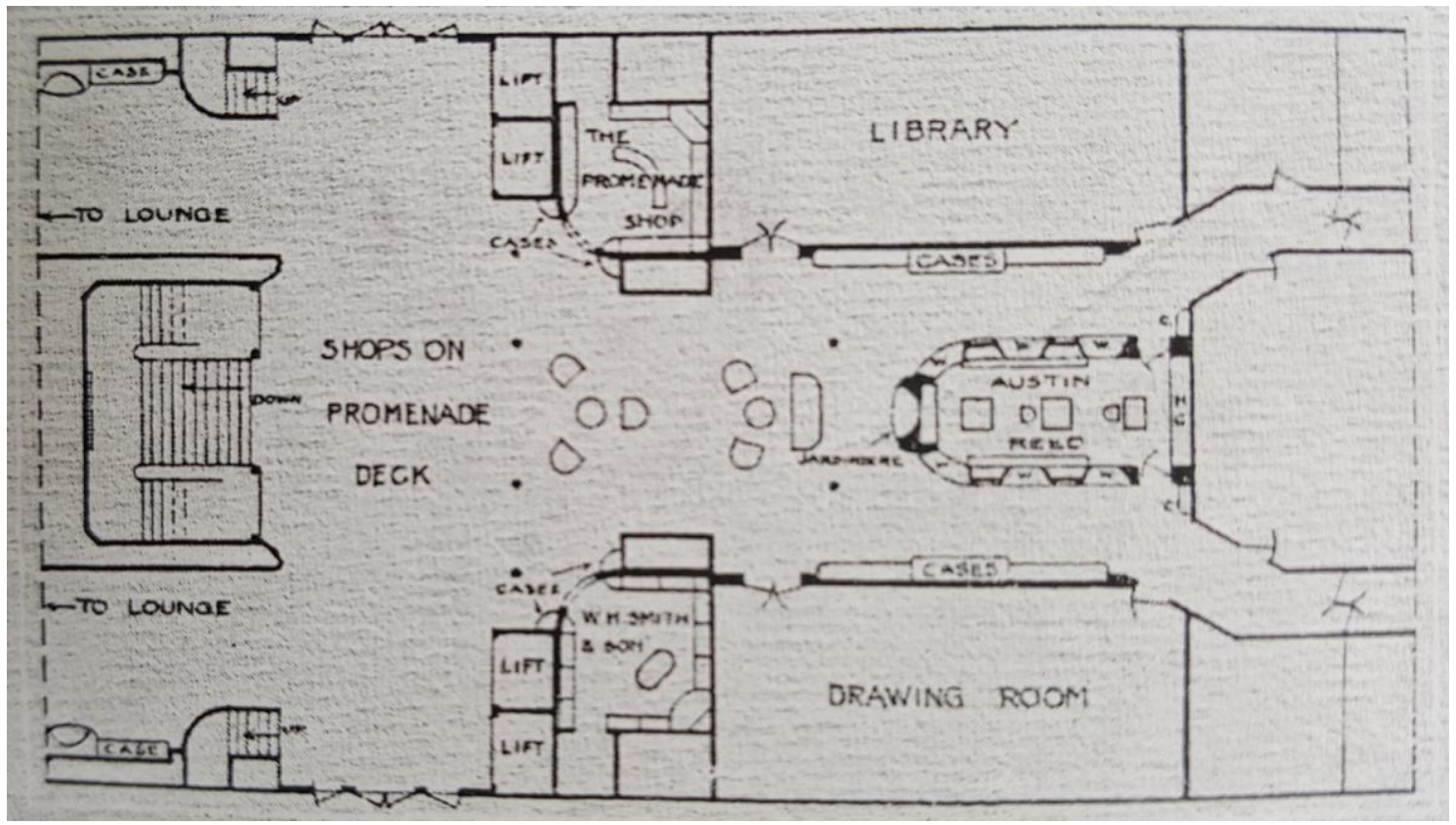

Figure 6 Plan of the Queen Mary's promenade deck 'shopping centre'. Hartnell, A. P. (1942) Shop Planning and Design. (London: Bloomsbury, 1942): 87.

The prominent shop window displays lining the shopping halls were critical for engaging with promenading passengers. The Queen Mary's promenade deck was lined with 24 display cases, framed in silver bronze. Retail display was increasingly professionalised, drawing on new ideas about marketing, consumer psychology and modern design. ${ }^{41}$ The shopping hall's sleek surfaces and enticing displays can be 
understood as part of a circulation strategy, operating in conjunction with intricate floor plans. (Figure 6) The pattern laid in the polished 'Korkoid' lino-type flooring created paths and routes echoing the pavements and streets of the West End. Austin Reed would have been delighted to have secured their prominent cabin-like shop in the centre of the Queen Mary's prominent deck. This was in essence a miniature 'island site', the mainland shop sites which were surrounded enclosed by streets on all (or most) sides. These sites were much sought after by urban retailers, due to their extended interface with passing pedestrians, increased display capacity and multiple apertures. ${ }^{42}$ 


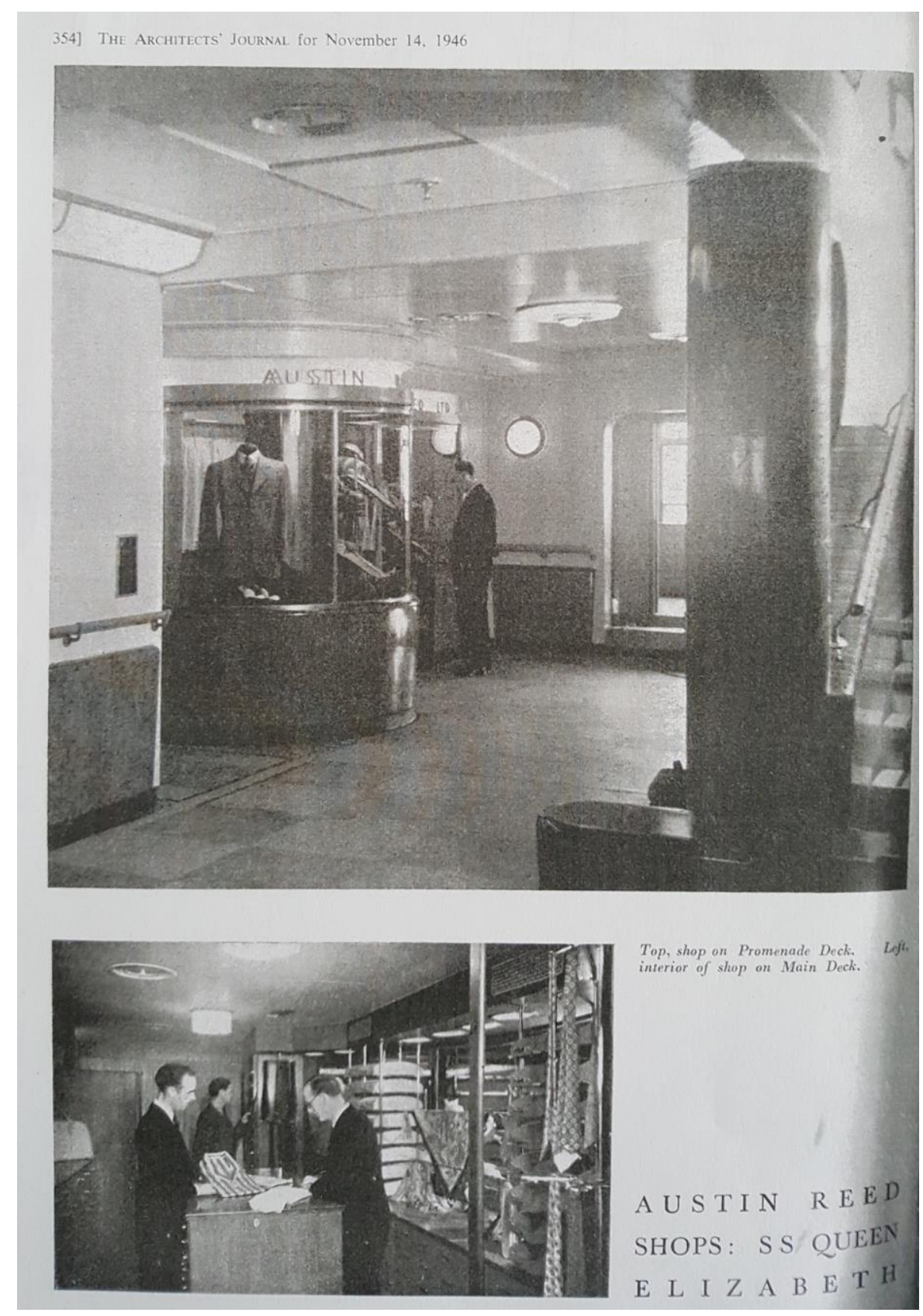

Figure 7: Austin Reed shops on the Queen Elizabeth, Architects' Journal, (14

November 1946): 354

Inside the liners' bijou menswear stores, the styling of mid twentieth century shop fitting drew heavily on the yacht and cabin, as did the restrained cabinetry of their mainland shops. It was common at this time for carpentry firms to combine work as shop fitters and boat fitters. Both sets of clients demanded efficient storage systems, concealed behind sleek surfaces. Interior detailing was seen as highly important in the 
retail sector as a whole, fixtures and fittings accounting for over half the total cost of a new shop, worth the investment because of their role in securing sales. ${ }^{43}$ P.J. Westwood \& Sons' design for Austin Reed on the Queen Mary was an neat but intricate jigsaw of drawers, trays and fittings, all designed to withstand the roll of the ship. ${ }^{44}$ The Architects' Journal's review of the Austin Reed shops on board the Queen Elizabeth noted how designers slotted in efficient filing systems for clothes, tucked in niches between ventilation shafts and service ducts, beneath showcase windows, all fed from a stock room in the hold, 'In designing the shops the biggest problem was to accommodate a serviceable number of drawers and fixtures and still leave room to move inside... The shops are fitted with trays and drawers in standardized sizes to take flannel trousers, shirts, collars, etc., and fitted cabinets to take coats on hangers..., 45 Cut off from usual retail supply systems, as much stock as possible needed to be stowed onboard. Storage needed to be balanced against the requirement for uncluttered shop interior and displays. A modern store like Austin Reed needed clear space and clean lines to communicate desirably fashionable modernity. 'Not only must there be physical room but a feeling of space must be attained so that these small shops do not look like mere kiosks. The bowed shapes of the main deck shop give a spaciousness' ${ }^{46}$

It seems that architects considered ships to be 'buildings' in several key respects. They were 'designed' by architects, and new liners were reviewed extensively in their trade journals. A prominent strand within mid twentieth century professional architectural discourse concerned the integrity and appropriateness of designs for specific environments. This concern was central to debates about both multiple retail shops and liner interiors. Modernist critic John de La Valette discussed the appropriateness of modern liner interiors being 'of the land' or 'of the sea' ${ }^{47}$ Prominent town planner Patrick Abercrombie decried 'The multiple shops are amongst the worst 
offenders... Their brutal stock fronts botched on to older buildings ... bring a shout of town vulgarity that drowns the quiet charm of the place. ${ }^{48}$ The period was marked by the dramatic expansion of chain stores, when now familiar brands claimed a foothold on the highstreets of cities and major towns. ${ }^{49}$ In 1939 Austin Reed had a portfolio of 30 shops across Britain, and Simpson's had concessions in department stores. The modern architectures adopted by these companies protected them from the critics' scorn, retail architecture could not entirely shrug off associations with the feminised, showy and chaotic pleasures of consumption. The building type essentially prioritised surface, novelty and luxurious styling over serious and structural modern intent.

It is significant that Austin Reed used their regular architects and house design for their liner store, ensuring the transatlantic branches were incorporated into their wider network. ${ }^{50}$ This network was connected by architecture, display, advertising and goods. However, rather than telling a story of ageographic homogeneity, the brand maintained a strong connection with a very specific metropolitan geography, with the strapline ‘Austin Reed of Regent Street'. 'Simpson Piccadilly’ used similar strategies with its network of small concessions. Lanz's work on the interiors of 1930s Italian liners describes the emergence of a national modern 'naval' design style, moving away from sumptuous designs echoing elite mainland hotels and villas 'mak[ing] passengers forget that they were on board a ship ${ }^{51}$ Something different seems to have been going on in the interior spaces of Cunard liners, reflecting a differently composed relationship between national cultures, leisure consumption and design, evoking a hyper-real Regent Street. 
Liners were equipped with hairdressers and gift shops, but there were no equivalent opportunities for women's fashion retailers on these mid-century ships. Onboard the 1936 Queen Mary, Austin Reed was the largest and most prominently positioned of three shops, the others being a W. H. Smiths bookshop and gift shop / tobacconist. This unsettles our understandings of the close connection between leisure and feminine consumption in the nineteenth and twentieth centuries. ${ }^{52}$ However it was very much in accordance with the Department of Trade's promotion of British goods and services overseas throughout the period, but particularly in the aftermath of WW2. Menswear, particularly Savile Row tailoring, was heavily pushed, and womenswear retailing overlooked. Alongside this was the emergence of a new acceptability of masculine consumption as a leisure activity, evidenced and exploited by a series of new retail spaces.

The Architects Journal noted of Austin Reed on the Queen Elizabeth that 'The use of English elm veneers with mahogany surrounds gives the masculine character to the design required by the firm. ${ }^{53}$ The 'man's shop' was actually one of a number of liner spaces designed and styled to evoke masculinity. Architectural Design and Construction reviewed the Queen Mary's substantial smoking room, 'The main conception here is an attempt to achieve the solid comfort of a typically English club or country house smoking room' ${ }^{54}$ Solid in some respects, overall an aesthetic of surface treatments: wood veneers, fabrics, glazing, through which fashionable English masculinity was 'staged'. This styling in line with established strategies of demarcating separate liner spaces for men and women through design, as in mainline shops and other architectural spaces. ${ }^{55}$ Similarly, Ocean Times advertisements presented a version of London's fashionable shopping streets which highlighted geographies and cultures of masculine consumption. Department store advertisements had inflections of masculinity 
that were largely lacking in mainland equivalents.

When Building reviewed the Queen Elizabeth launched in 1946, it was struck by the seemingly outdatedness of the décor, designed by architect Grey Wornum in the 1930s and delayed by war, "To board the newly refitted "Queen Elizabeth" ... is to escape to yesterday'; everything was too rich and sumptuous, already out of sync with the grey and pared back aesthetic of austerity Britain. ${ }^{56}$ Yet Cunard and the onboard retailers weren't just addressing still-depleted, coupon-dependent British men. Here we come back to the point that they were appealing primarily to the prized affluent American tourist with his preference for English traditions and history.

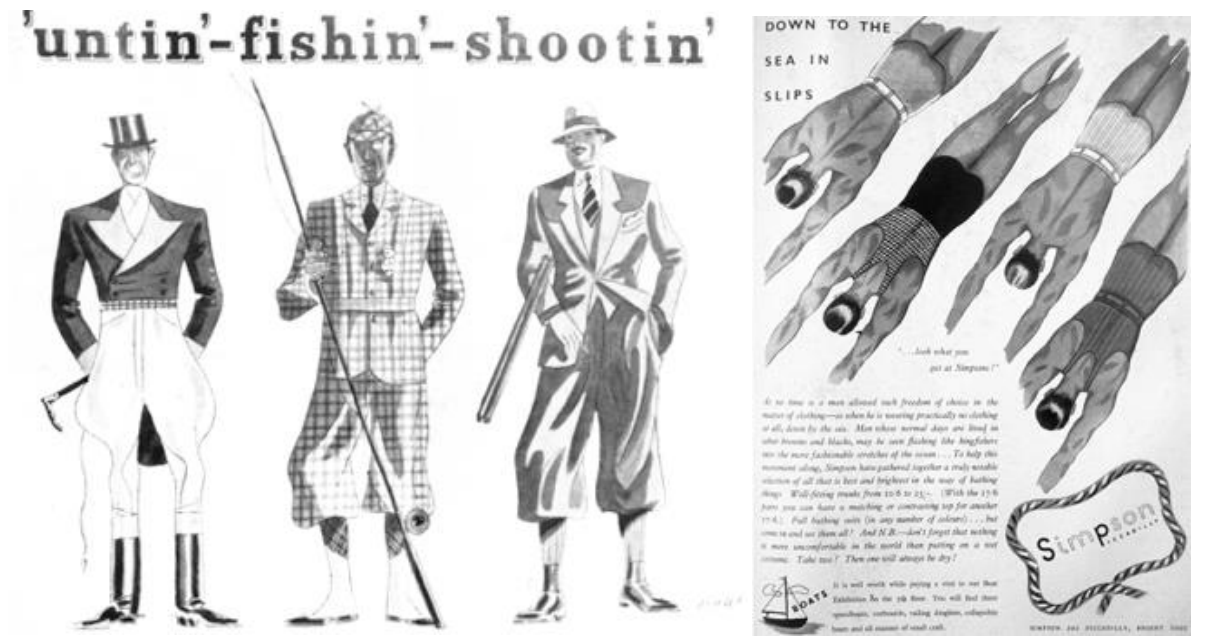

Figure 8 Simpsons advertisements July 1936, By courtesy of the Daks Simpsons Archive.

The advertisements of West End retailers in the liner newspapers placed significant stress on traditional masculinity, when they were more likely to stress modernity in mainland campaigns. This is apparent when two Simpsons advertisements from July 1936 are set side by side. (Figure 8) Both feature masculine sporting pursuits, the first placed in onboard passenger papers including the Canadian Pacific Gazette and Ocean Times, the other in the London local paper, the Evening News. In the Evening 
News the swimwear advertisement 'Down to the Sea in Slips' used a strikingly modern graphic style, and showed a group of muscled, sun-tanned, bodies wearing modern jersey swimming trunks, 'flashing like kingfishers into the more fashionable stretches of the ocean. ${ }^{57}$ Cruising and liner travel were presented as modern and modish leisure activities, requiring a stylish wardrobe. In contrast, the advertisement "'untin', fishin', shootin"" in the liner papers promoted traditional elite sporting cultures and clothing, with a much more aristocratic, buttoned-up look. ${ }^{58}$ This message was echoed in the polished plaster decorative frieze above the Queen Mary shop windows, featuring nostalgic sporting tableaux. This is what retailers believed that American tourists were looking for.

Both advertisements and the design and organisation of the shops themselves reflect the careful and complex spatial ordering of social life along class lines aboard the liner. ${ }^{59}$ When this was combined with the unsettling of national borders, the liner became a potentially lucrative breeding ground for insecurities about appropriate dress. A Simpsons advertisement placed in the Canadian Pacific Gazette and Ocean Times exploited these, 'however stoutly the Englishman may affect a careless indifference towards dress ... some of the worst predicaments in English life are associated with "the wrong clothes" ... The unforgivable sin is not doing the wrong thing, but doing it in the wrong clothes' ${ }^{60}$ This message was pressed home repeatedly in editorial content, advising passengers on elite masculine dress cultures: 'Dress as they do; dress simply, as they do, because they like conformity. If you play golf in riding breeches you will shock and grieve them. But you will shock them even more if you show such bad taste as to be "overdressed". ${ }^{61}$

The primary aim of Austin Reed and Simpsons' transatlantic marketing operations was to take a claim as providers of traditional upmarket masculine dress. The 
vulnerability of their new kinds of menswear retailing lies behind their confident claims. Research by Honeyman and Ugolini has demonstrated the complex, class-inflected relationship between ready-to-wear and traditional tailoring in the inter-war years. It is clear that in several quarters consumer ambivalence continued towards ready-to-wear tailoring, right at this very moment of its flourishing. ${ }^{62}$ In this context, retailers' lavish advertising, and investment in their liner operations on top of domestic expansion, can be seen as brave and risky. It was also instrumental in securing the shift in masculine consumption cultures they needed to thrive. Art and Industry reviewed Simpsons' late 1930s advertising, 'It has been almost exclusively a campaign of ideas: of the Simpson ability to dress men stylishly and correctly. The description and presentation of merchandise has been made secondary to the Simpsons theme... Simpsons have attempted to replace on a very much wider basis the Savile Row idea of professional relationship' ${ }^{63}$

\section{Conclusions}

By shaping the fabric of liner interiors, and by extensive advertising in the pages of onboard magazines, menswear retailers marked out their onboard shops as West End outposts. They collapsed and stretched geographies, sometimes obscuring, sometimes highlighting cultural differences between passengers. This research has invited a fresh look at the 'placelessness' of the liner. It is suggested that the identity of liner spaces and the imagined geographies of passengers were ripe for manipulation by the retail architect and ad man precisely because of their unstable geographies.

These small shops were set in the context of glamourous liner interiors which evoked the smart hotel, and could themselves be either 'nowhere' or 'everywhere'. This 
disruption of familiar retail and leisure geographies foreshadows later twentieth century debates about lack of local distinctiveness: the high street, the mall, the internet. Certainly, at this moment, broader ideas were developing about the potential for the 'nowhere' places / 'places in transit' as opportunities for retail and consumption. For example, the potential of urban transport networks was being recognised for reaching a captive, kinetic audience of millions. For example, a 1938 London Transport campaign promoted its underground train poster space as 'A shop window as wide as London.' ${ }^{\text {'64 }}$

Alternatively, liner shops can be read, as has been demonstrated here, as distinctly metropolitan spaces, where residents of one city stepped seamlessly into another. This involved the retailers' deliberate denial of this as an 'other' space. Their hyperreal West End was set to work mitigating against the physical and cultural instabilities of the journey. This was the view of the Architect and Building News review of the Queen Mary 'For the public there is only one imaginative criterion by which the quality of a great liner is measured, and that is the degree to which land conditions are reproduced afloat. The entire romance of ship deign resides in the sensational contrast between the cold, frightening inhumanity of the steel hull, cutting its way through the ocean, and the cosy, intimate warmth of an interior in which all the minutiae of ordinary life are reproduced' ${ }^{65}$

Part of the cosiness consisted of representing London's masculine consumption and its geographies as consistently traditional throughout the 1930s to 1960s. Readers of the Ocean Times would have realised that Swinging London existed, if not for a reference in a single article from 1966, where passengers were warned of the arrival of Carnaby Street, 'if the visitor is a conservative dresser and not so young, he must tread his way around animated groups of gaily dressed youngsters who gather daily to see the big, gleaming cars of the pop star clients of the boutique'. ${ }^{66}$ 
There is a poignancy in these stylish liners and their modern retailers so quickly becoming the outdated province of the 'not so young conservative dresser'. The Queen Mary was decommissioned in 1967, the Queen Elizabeth in 1968. The liner companies should perhaps have seen this coming, instead of pouring resources into post-war refits and in 1963 commissioning new liner, the QE2, launched in $1969 .{ }^{67}$ By 1956 numbers of air travellers had overtaken liner passengers. ${ }^{68}$ On the other hand, during the post war years the ocean liner remained an emblem of luxury, repeatedly referenced in new forms of leisure architecture. ${ }^{69}$ It is clear the liner still held some power to seduce liner company boards, retailers and passengers alike.

1 ‘Telling Tails', L'Atlantique SS “Normandie” (22 August 1936).

${ }^{2}$ Neil McCart, Atlantic Liners of the Cunard Line: from 1884 to the Present Day, Wellingborough: Stephens, (1990).

${ }^{3}$ Architectural Design and Construction, June 1936, 264.

${ }^{4}$ H. Taylor Rose, 'Contemporary Men's Wear Shop Design', in Men's Wear Display: A Practical Work on Window Showmanship and Interior Planning and Equipment, Albert Edward Hammond ed. (London: Caxton c.1930), 91.

${ }^{5}$ Men's Wear, 23 March 1929, 407.

${ }^{6}$ Bronwen Edwards, 'A Man's World? Masculinity and Metropolitan Modernity and Simpson, Piccadilly', Geographies of British Modernity, David Gilbert, David Matless and Brian Short eds., (Oxford: Blackwell, 2003): 151-167; Jobling, Man Appeal; Berry Ritchie, A Touch of Class : The Story of Austin Reed, (London: James \& James, 1990); David Wainwright, The British Tradition: Simpson - a World of Style. (London: Quiller Press, 1996). 
${ }^{7}$ Bronwen Edwards 'The Department Store: the Metropolitan Flagship in National Networks of Fashion Consumption', Flagship Marketing: Concepts and Places, eds. Tony Kent and Reva Brown, (London: Routledge, 2009.): 125-143.

${ }^{8}$ Austin Reed's sector-leading advertising at this time is discussed in Paul Jobling, Man Appeal: Advertising, Modernism and Menswear, (Oxford: Berg, 2005); Paul Jobling,' "Virility in Design": Advertising Austin Reed and the "New Tailoring" during the Interwar Period in Britain'. Fashion Theory 9 no. 1 (2005): 57 - 84.

${ }^{9}$ Honeyman, Katrina. 2002. 'Following Suit: Men, Masculinity and Gendered Practices in the Clothing Trade in Leeds, England, 1890-1940' Gender \& History 14, no. 3: 426446; Ugolini, Laura. Men and Menswear: Sartorial Consumption in Britain, 1880-1939, Aldershot: Ashgate, 2007; Ugolini, Laura. Ready-to-wear or Made-to-measure? Consumer Choice in the British Menswear Trade, 1900-1939’ Textile History no. 2 (2003): 192-213. ${ }^{10}$ Christopher Breward, The Hidden Consumer: Masculinities, Fashion and City Life, 1860 1914 (Manchester: Manchester University Press, 1999); Edwards, ‘A Man’s World?; Jobling, Man Appeal.

${ }^{11}$ The work on urban consumption history is well established, rich and varied. See for example Sonia Ashmore, Bronwen Edwards, and David Gilbert. "'Mr Bourne's dilemma'. Consumer culture, property speculation and department store demise: the rise and fall of Bourne and Hollingsworth on London's Oxford Street." Journal of Historical Geography 38, (October 1, 2012): 434-446; Breward, The Hidden Consumer; Mark Jayne, Cities and Consumption, (London: Routledge, 2006); Hazel Hahn, Scenes of Parisian Modernity: Culture and Consumption in the Nineteenth Century, (Basingstoke: Palgrave Macmillan, 2009); Louisa Iarocci, The Urban Department Store in America, 1850-1930, (Aldershot: Ashgate 2014).

${ }^{12}$ This literature is extensive and multidisciplinary in approach. See for example Rachel Bowlby, Carried Away: The Invention of Modern Shopping (London: Faber, 2000); Richard Longstreth, City Center to Regional Mall: Architecture, the Automobile, and Retailing in Los Angeles, 1920-1950, Cambridge, Mass.: MIT Press, 1997); Erika Rappaport, Shopping 
for Pleasure: Women and the Making of London's West End (Princeton, Princeton University Press: 20000).

${ }^{13}$ Richard Longstreth, The American Department Store Transformed, 1920-1960, London: Yale University Press, 2010, chapter 5.

${ }^{14}$ Anyaa Anim-Addo, William Hasty, and Kimberley Peters, 'The Mobilities of Ships and Shipped Mobilities', Mobilities 9, no. 3 (2014): 337-349; William Hasty and Kimberley Peters, 'The Ship in Geography and the Geographies of Ships', Geography Compass 6 no. 11, (2015): 660-676; David Lambert, Luciana Martins and Miles Ogborn, 'Currents, Visions and Voyages: Historical Geographies of the Sea', Journal of Historical Geography 32, no. 3, (2006): 479-493.

${ }^{15}$ Francesca Lanz, 'The Interior Decoration of Ocean Liners: A Chapter in Italian Design History', Interiors 3 no. 3 (2012):250; Anne Wealleans, Designing Liners: A History of Interior Design Afloat, (London and New York: Routledge, 2006): 2.

${ }^{16}$ Douglas Hinkey, Cynthia MacMullin, and Ronald Smith, The Art of the RMS Queen Mary. (US: Robert Gumbiner Foundation, 1994); Lanz, 'The Interior Decoration of Ocean Liners'; Anne Massey, 'Nationalism and Design at the End of the Empire: Interior Design and the Ocean Liner', in Designing the Modern Interior: from the Victorians to Today, Penny Sparke, Anne Massey, Trevor Keeble, and Brenda Martin eds. (Oxford: Berg, 2009): 207218; Gregory Votolato, Ship. (London: Reaktion, 2011); Fiona Walmesley, 'Pragmatism and pluralism: The interior decoration of the "Queen Mary", Interior design and identity, Susie McKellar and Penny Spark eds. (Manchester: Manchester University Press, 2004): 55-73. Wealleans, Designing Liners.

${ }^{17}$ Le Corbusier, Towards a New Architecture, (London: Architectural Press, 1970); Wealleans, Designing liners; Peter Quartermaine, Building on the Sea: Form and Meaning in Modern Ship Architecture, (London: Academy Editions, 1996).

${ }^{18}$ See for example Simpson Piccadilly menswear catalogue c.1950. V\&A National Art Library TLC. 1.748

${ }^{19}$ Simpsons Staff Magazine, Trend, 62 no. 5 (June 1952): 6-7. 
20 'What London is Wearing: Style Pointers for Overseas Readers', Menswear (11 May 1929): 208.

${ }^{21}$ Advertisement Evening News 19 July 1938.

${ }^{22}$ Advertisement, Ocean Times (May 1947): 2.

23 'Advertising for Men Only’, Art and Industry, (July 1939): 1.

${ }^{24}$ Advertisement, Evening Standard (1 February 1930).

${ }^{25}$ Ocean Times RMS “Queen Elizabeth” North Atlantic Edition (21 January 1947): 4.

${ }^{26}$ McCart, Atlantic Liners of the Cunard Line.

${ }^{27}$ Simpsons Board of Directors' minutes (24 June 1947), Daks Simpson archive.

${ }^{28}$ Ocean Times RMS “Queen Elizabeth” North Atlantic Edition. (21 January 1947): 6

${ }^{29}$ Simpson Piccadilly menswear catalogue V\&A National Art Library TLC.1.748 (c.1950)

30 'London's Heart', Ocean Times RMS “Queen Elizabeth” (16 April 1966): 4.

${ }^{31}$ Advertisement, Ocean Times, RMS "Queen Elizabeth"(13 May 1967): 5.

${ }^{32}$ David Griffiths, 'London's Heart', Ocean Times, RMS “Queen Elizabeth" (13 May 1967): 5.

${ }^{33}$ Commercial Art (1930)

${ }^{34}$ Bryan Westwood and Norman Westwood, Smaller Retail Shops, (London: The Architectural Press, 1937).

${ }^{35}$ Cabinet Maker, (January 1937): 14.

${ }^{36}$ Letter from Alexander Simpson to his store architect Joseph Emberton (20 April 36), Daks Simpson Archive.

${ }^{37}$ The Story of R.M.S. Queen Mary. A Descriptive Souvenir, Etc. (London: George Newnes, 1936): 38 .

${ }^{38}$ Ibid: 41.

${ }^{39}$ Archibald Hartnell, Shop Planning and Design. (London: Bloomsbury, 1942): 87; The Story of R.M.S. Queen Mary: 41.

${ }^{40}$ Architecture Illustrated (June 1936): 183.

${ }^{41}$ Hammond ed. Men's Wear Display.

${ }^{42}$ Westwood and Westwood, Smaller Retail Shops: 16-20. 
${ }^{43}$ Westwood and Westwood, Smaller Retail Shops: 83.

${ }^{44}$ Westwood and Westwood, Smaller Retail Shops: 56.

${ }^{45}$ Architects' Journal, (14 November 1946): 351.

${ }^{46}$ Ibid

${ }^{47}$ John de la Valette, 'The Fitment and Decoration of Ships from the Great Eastern to the Queen Mary', Journal of the Royal Society of Arts (84, 1930): 705-726.

${ }^{48}$ Cited in A. Edward Hammond, Multiple Shop Organisation, (London: Sir Isaac Pitman and Sons, 1930): 134.

${ }^{49}$ Hammond, Multiple Shop Organisation.

${ }^{50}$ Hartnell, Shop Planning and Design: 87.

${ }^{51}$ Lanz, 'The Interior Decoration of Ocean Liners': 251

${ }^{52}$ See for example Mica Nava, 'Modernity's disavowal: women, the city and the department store', The Shopping Experience, Pasi Falk and Colin Campbell eds. (London, Sage: 1997); Erika Rappaport, Shopping for Pleasure.

${ }^{53}$ Architects' Journal, (14 November 1946): 351.

${ }^{54}$ Architectural Design and Construction, (June 1936): 264.

${ }^{55}$ Anne Massey, 'A Feminine Touch: Gender, Design and the Ocean Liner', Journal for Maritime Research 17 no. 2 (2015): 169-181.

${ }^{56}$ Building (October 1946): 292.

${ }^{57}$ Simpsons Advertisement, 'Down to the Sea in Slips', Evening News, (9 July 1936).

${ }^{58}$ Simpsons Advertisement, “'untin', fishin', shootin'”, Canadian Pacific Gazette and Ocean Times, (July 1936).

${ }^{59}$ Existing work had drawn attention to the liner as a space where rigid class hierarchies were reflected and produced. See Graham Gladden, 'Marketing ocean travel: Cunard and the White Star Line, 1910-1940’, Journal of Transport History 35, no. 1 (June 2014): 57-77; Lanz, 'The Interior Decoration of Ocean Liners; Wealleans, Designing Liners.

${ }^{60}$ Simpsons Advertisement, 'untin', fishin', shootin', Canadian Pacific Gazette and Ocean Times, (July 1936). 
61 'On Learning to Know the English: Witty Frenchman's solemn hints on how to understand them' Ocean Times RMS Majestic 26 November 1934): 2.

${ }^{62}$ Honeyman, 'Following Suit'; Ugolini, Men and Menswear'; Ugolini, 'Ready-to-wear or Made-to-measure?'

63 'Simpson Advertising: a campaign of ideas. Art and Industry, June 1937, p. 245.

${ }^{64}$ London Transport advertising, 'A Shop Window as Wide as London', Art and Industry, (1938 cover)

${ }^{65}$ The Architect and Building News (1936)

${ }^{66}$ Ocean Times, (19 September 1966): 3

${ }^{67}$ Massey, 'Nationalism and design at the end of the empire'.

${ }^{68}$ Neil McCart, Atlantic Liners of the Cunard Line:13.

${ }^{69}$ Alice T. Friedman, 'Ship Shapes: Ocean Liners, Modern Architecture and the Resort Hotels of Miami Beach', in Designing the Modern Interior: from the Victorians to Today ed. Penny Sparke, Anne Massey, Trevor Keeble, and Brenda Martin (Oxford: Berg, 2009): 195-206. 